\section{Quality assessment of clinical guidelines for the treatment of obesity in adults: application of the AGREE II instrument}

\author{
Avaliação da qualidade das diretrizes clínicas \\ para o tratamento da obesidade em adultos: \\ aplicação do instrumento AGREE ॥
}

\section{Evaluación de la calidad de guías clínicas para el tratamiento de la obesidad en adultos: aplicación \\ del instrumento AGREE II}

Erika Cardoso dos Reis 1

Sonia Regina Lambert Passos 2

Maria Angelica Borges dos Santos 1

\author{
Correspondence \\ E. C. Reis \\ Escola Nacional de Saúde Pública Sergio Arouca, Fundação \\ Oswaldo Cruz. \\ Rua Leopoldo Bulhões 1480, Rio de Janeiro, RJ 21041-210, \\ Brasil. \\ erika.careis@gmail.com \\ ${ }^{1}$ Escola Nacional de Saúde Pública Sergio Arouca, Fundação \\ Oswaldo Cruz, Rio de Janeiro, Brasil. \\ 2 Instituto Nacional de Infectologia Evandro Chagas, Fundação \\ Oswaldo Cruz, Rio de Janeiro, Brasil.
}




\section{Introduction}

Obesity is a chronic, multifactorial disease, that has been increasing at alarming rates worldwide. A recent analysis on trends in adult body mass index (BMI), based on data from 200 countries, showed that between 1975 and 2014 the age-standardized global mean BMI in men increased from 21.7 to $24.2 \mathrm{~kg} / \mathrm{m}^{2}$. In the same time interval, age-standardized prevalence of obesity $\left(\mathrm{BMI} \geq 30 \mathrm{~kg} / \mathrm{m}^{2}\right)$ increased from $3.2 \%$ to $10.8 \%$ in men and from $6.4 \%$ to $14.9 \%$ in women 1 . This rapidly growing prevalence in recent decades has turned obesity into a serious public health problem in both developed and developing countries, and currently obesity is considered a global epidemic.

The impact of obesity on quality of life has been widely discussed. Obesity is also an important risk factor for other chronic non-communicable diseases (NCDs) such as diabetes, arterial hypertension, musculoskeletal disorders (especially osteoarthritis), and some types of cancer (mainly endometrial, breast, and colorectal) 2 .

According to the Brazilian National Health Survey, 36.1\% of Brazil's adult population are overweight (BMI defined between $25 \mathrm{~kg} / \mathrm{m}^{2}$ and $30 \mathrm{~kg} / \mathrm{m}^{2}$ ), of which $20.8 \%$ are obese (BMI greater than $\left.30 \mathrm{~kg} / \mathrm{m}^{2}\right)^{3}$. Given this scenario, the Brazilian Unified National Health System (SUS) has endeavored to organize care pathways for obesity since 20134 . Care pathways are organizational arrangements of health interventions and health services that seek to rationally incorporate the best available evidence on treatment protocols, guidelines and multidisciplinary clinical practice 5 .

Literature emphasizes the need for up-to-date, concise, and accessible information produced by reliable sources to orient health practices 6 . Clinical guidelines are defined by the Institute of Medicine as structured recommendations developed to orient health professionals on appropriate health care in specific clinical circumstances 7. They include treatment indications and contraindications, as well the expected benefits and risks from the use of health technologies (for example: procedures, diagnostic tests, medicines) for specific patient groups.

Clinical guidelines based on the best available scientific evidence aim to optimize health professionals' decisions, and play a key role in health systems management and regulation 7,8,9,10. Health professionals, administrators, and funders view guidelines as tools that can reduce the gap between professionals' routine clinical work and orientation from scientific evidence on such practice 10,11.

Taba et al. 12 found that physicians do not consider the use of clinical guidelines as a hindrance to their professional autonomy, which theoretically facilitates their adherence to (and use of) such guidelines. Good-quality guidelines can provide less uncertainty in clinical decision-making and support health professionals in their health education process and in dealing with questions on their clinical practice 13 .

The increase in the production of clinical guidelines in recent years raises the concern that many clinical guidelines may not have the requirements to be classified as such, due to their low quality. This creates the need to internationally define acknowledged criteria for their assessment 14 . This has led to standardized instruments for assessing the development and validity of clinical guidelines 15,16,17,18, including the Appraisal of Guidelines for Research er Evaluation (AGREE II) instrument 16.

The AGREE II 19 has been gradually incorporated in Brazil in the last two years, having been applied to guidelines produced by the Brazilian Ministry of Health 20, in the assessment of a set of Brazilian clinical guidelines for NCDs 21 , and supporting the production of clinical guidelines by medical experts 22,23 .

Given the diversity of published guidelines and the uncertainty surrounding their quality in a scenario of growing demand for the implementation of care pathways for obesity in the SUS, this study aims the assessment of the quality of clinical guidelines for obesity in adults, produced worldwide from 1998 to 2016.

\section{Methods}

This is a review of the quality of clinical guidelines for the treatment of obesity according to the AGREE II criteria 19. A search was conducted for clinical guidelines for the treatment of obesity in adults, published from 1998 to 2016, in the National Guideline Clearinghouse (NGC), Guidelines 
International Network (GIN), PubMed (MEDLINE), Scopus, Web of Science, and websites of health institutions and medical specialty societies.

To identify the clinical guidelines in the database indexes (PubMed, Scopus, and Web of Science), we used the following search strategies: (1) for PubMed - title (practice guideline) and MeSH terms (obesity); publication type (practice guideline) and MeSH terms (obesity); (2) for Scopus - title (practice guideline) and title (obesity); title (clinical practice guideline) and title (obesity); (3) for Web of Science - title (practice guideline) and title (obesity); title (clinical practice guideline) and title (obesity). The term "obesity" was used in the GIN website. In the NGC website, the term "obesity" was used and the target population characteristics/age selected were: adult (19-44 years) and middle age (45-64 years).

Inclusion criteria were: (1) clinical guidelines for obesity; (2) treatment recommendations for adults; (3) elaboration by a government agency and/or state-level societies of health professionals, because this allows greater comparability between guidelines in terms of scope and resources; and (4) studies published from 1998 to 2016. Exclusion criteria were: (1) clinical guidelines dealing exclusively with obesity associated with another health condition; (2) clinical guidelines dealing exclusively with obesity during life phases other than adulthood; and (3) non-inclusion of treatment recommendations for adults. There was no limitation on any language and the Google Translator tool was used when necessary to translate a guideline into English or Portuguese.

A total of 746 records were identified, of which 725 were excluded for not fitting into the inclusion criteria (Figure 1). Twenty-one clinical guidelines were included and assessed by a pair of appraisers/authors: a nutritionist (E.C.R.) and one of two physicians (S.R.L.P. or M.A.B.S.). The quality of the guidelines was assessed with the translated version of the AGREE II instrument, cross-culturally adapted to Brazilian Portuguese 24 .

AGREE II aims to analyze the methodological rigor of the development of clinical guidelines and orientation on information they are expected to contain 19. This instrument has 23 items, covering six domains of health care quality, consisting of items scored on a Likert scale from one to seven, in which one is "strongly disagree" and seven is "strongly agree".

The user's manual 19 provides guidance on how to score each item using the rating scale. Each appraiser scores the items of a domain independently, according to the 7-point scale $(1-$ strongly disagree to 7 - strongly agree), and the scores are not subjected to consensus. Scores of a domain are calculated by summing up the scores of the individual items in this domain and the total is calculated as a percentage of the maximum possible score for that domain. Thus, the maximum possible score for each domain is rated on a 7-point scale using the scores X number of items in the domain $\mathrm{X}$ number of appraisers.

Domain (1), "scope and purpose", assesses whether the guideline is clear in its overall objective, in the specific health issues to which it refers, and its target population (patients and public). It has three items (1-3) and maximum score per appraiser is 21.

Domain (2), "stakeholder involvement", assesses whether the guideline clearly defines the target population and participation of the stakeholders in its development, including different health professionals and patient groups in its elaboration. It also assesses whether the guideline reflects the views of the expected users and target populations. This domain has three items (4-6) and maximum score per appraiser is 21 .

Domain (3), "rigor of development" assesses the process of collection and synthesis of the evidence and the methods used to formulate the recommendations. It requires a clear description of the strengths and limitations of the body of evidence, consideration of the benefits, side effects, health risks in the formulation of the recommendations, the procedure for updating the guidelines, and external expert review. This domain has eight items (7-14) and maximum score per appraiser is 56.

Domain (4), "clarity of presentation", assesses whether the different options for approaching the health condition or problem are clearly presented, and more specifically whether the recommendations are clear, unambiguous, and easily identifiable. This domain has three items (15-17) and maximum score per appraiser is 21 .

Domain (5), "applicability", discusses facilitators and barriers for implementation of recommendations, strategies to improve application, and the necessary resources for such. This domain has four items (18-21) and maximum score per appraiser is 32. 
Figure 1

Flow diagram of the search for clinical guidelines.


Records after duplicates removed $(n=562)$
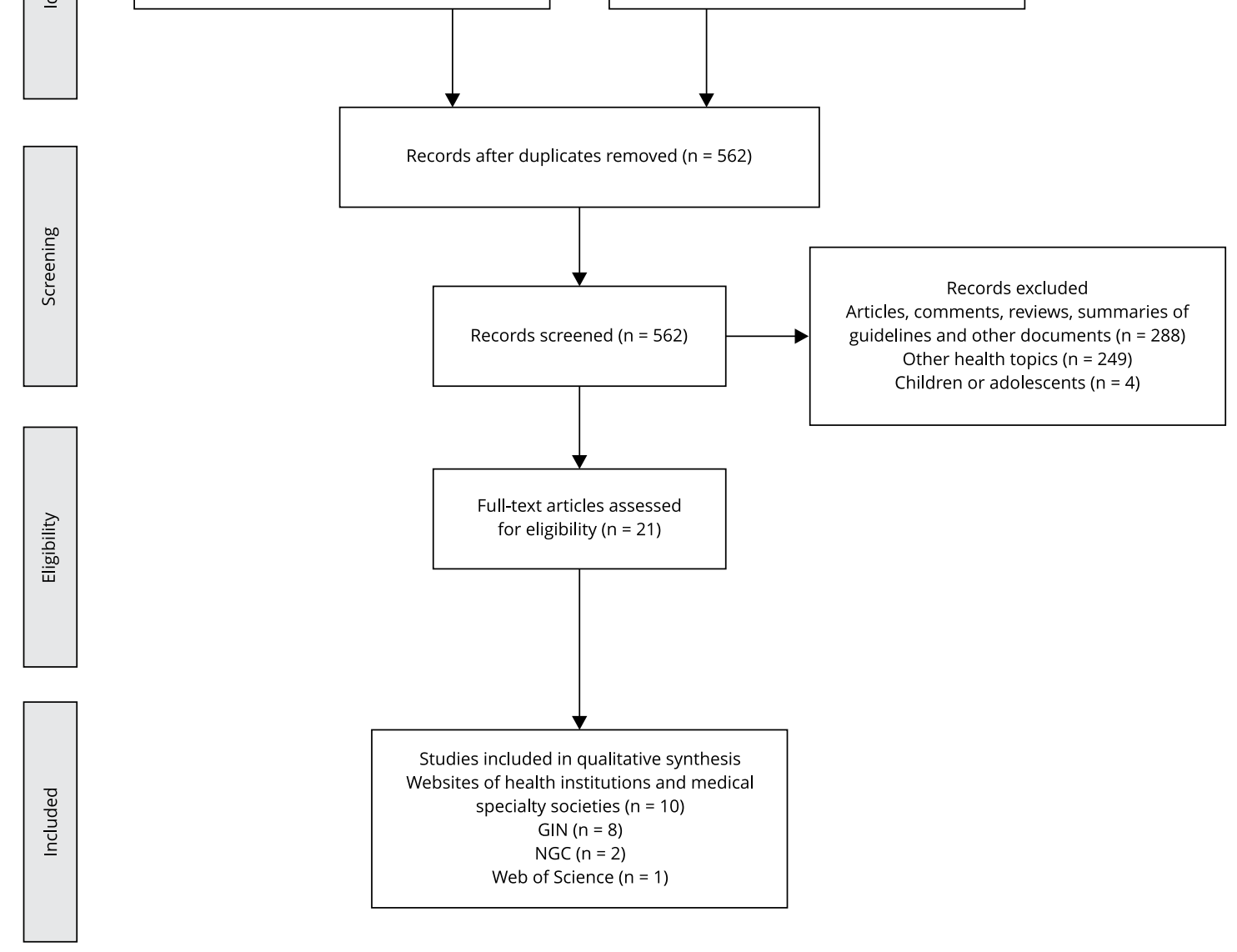

Studies included in qualitative synthesis Websites of health institutions and medical specialty societies $(n=10)$

$\operatorname{GIN}(n=8)$

$\operatorname{NGC}(n=2)$

Web of Science $(n=1)$

GIN: Guidelines International Network (http://www.g-i-n.net/); NGC: National Guideline Clearinghouse (https://www.guideline.gov/).

Domain (6), “editorial independence”, assesses potential conflicts of interest of professionals drafting the guideline, which might lead to biases in the recommendations. This domain has two items (22-23) and maximum score per appraiser is 14 .

AGREE II sets no standard scores for the domains to distinguish between high- and low-quality guidelines, which would help to define their recommendation or non-recommendation. This decision should be made by the evaluators and oriented by the context in which AGREE II is being used 19. According to the AGREE II User's Manual, the overall assessment of a guideline requires the appraiser to judge its quality.

Therefore, our cutoff for recommending a guideline was established by the appraisers. It considered the overall score attributed by appraisers to each guideline and a cutoff of recommendation closer to the highest possible score than to the lowest possible score, as follows: recommended (6.07.0), recommended with changes (4.0-5.9) and not recommended $(\leq 3.9)$. 
In addition to assessing the quality of guidelines according to AGREE II, the analysis was complemented by providing a brief description of the main therapeutic recommendations in the best scoring guidelines. Using the eight best scoring guidelines, the treatment recommendations found in 4 or more of them were selected and summarized. The main recommendations concerning diet, physical activity, psychological support, pharmacotherapy and surgery are shown in Table 1.

\section{Results}

Twenty-one clinical guidelines were identified from: Europe (Belgium 25, Finland 26, France 27, England 28, Germany 29, Italy 30, Netherlands 31, Norway 32, Scotland 33), North America (Canada 34 and USA: National Heart, Lung and Blood Institute - NHLBI 35, Defense Department 36, Institute for Clinical Systems Improvement - ICSI 37, American College of Cardiology 38 and American Association of Clinical Endocrinologists - AACE 39), Latin America (Argentina 40, Brazil 41, Mexico 42), Asia (Malaysia 43), Oceania (Australia 44) and one from the World Gastroenterology Organisation 45. No African clinical guideline was found (Table 2). One guideline was included although it represented a global organization and was not related specifically to one country. The database that yielded the most was the GIN.

Table 3 describes the overall assessment and scores of guidelines as shares of maximum total score per individual domain of the AGREE II.

Table 1

Main treatment recommendations in the best scoring-guidelines for adult obesity.

\begin{tabular}{|c|c|c|c|c|c|c|c|}
\hline Recommendations & Argentina 40 & Australia 44 & England 28 & France 27 & Mexico 42 & USA (ICSI) 37 & Germany 29 \\
\hline \multicolumn{8}{|l|}{ Dietary interventions } \\
\hline Reduce caloric intake (deficit of $500 \mathrm{Kcal}-1,000 \mathrm{Kcal}$ ) & $\bullet$ & $\bullet$ & $\bullet$ & - & $\bullet$ & $\bullet$ & $\bullet$ \\
\hline $\begin{array}{l}\text { Reduce caloric intake by restricting food } \\
\text { consumption (caloric intake and type of food not } \\
\text { specified) }\end{array}$ & - & - & - & $\bullet$ & $\bullet$ & - & $\bullet$ \\
\hline Very-low-calorie diets, under medical supervision & $\bullet$ & - & - & $\bullet$ & - & - & - \\
\hline \multicolumn{8}{|l|}{ Behavioral interventions } \\
\hline Cognitive-behavioral therapy & $\bullet$ & $\bullet$ & $\bullet$ & $\bullet$ & $\bullet$ & $\bullet$ & $\bullet$ \\
\hline \multicolumn{8}{|l|}{ Physical activity } \\
\hline Up to 150 minutes of physical exercise/week & - & $\bullet$ & $\bullet$ & $\bullet$ & $\bullet$ & - & $\bullet$ \\
\hline $150-300$ minutes of physical execise/week & - & $\bullet$ & $\bullet$ & $\bullet$ & $\bullet$ & - & - \\
\hline Aerobic exercise & $\bullet$ & - & - & - & $\bullet$ & - & - \\
\hline \multicolumn{8}{|l|}{ Pharmacological interventions } \\
\hline May be used in patients with $\mathrm{BMI}>30 \mathrm{~kg} / \mathrm{m}^{2}$ & - & $\bullet$ & $\bullet$ & - & $\bullet$ & $\bullet$ & $\bullet$ \\
\hline $\begin{array}{l}\text { Gastric and pancreatic inhibitors-Orlistat associated } \\
\text { with lifestyle interventions }\end{array}$ & $\bullet$ & $\bullet$ & $\bullet$ & - & $\bullet$ & $\bullet$ & - \\
\hline $\begin{array}{l}\text { In cases of treatment failure with other therapeutic } \\
\text { strategies (diet, exercise, psychotherapy) }\end{array}$ & - & - & $\bullet$ & - & $\bullet$ & $\bullet$ & - \\
\hline \multicolumn{8}{|l|}{ Surgical interventions } \\
\hline $\mathrm{BMI} \geq 35 \mathrm{~kg} / \mathrm{m}^{2}$ with comorbid conditions & - & $\bullet$ & $\bullet$ & - & - & $\bullet$ & $\bullet$ \\
\hline $\mathrm{BMI} \geq 40 \mathrm{~kg} / \mathrm{m}^{2}$ & $\bullet$ & - & - & - & - & $\bullet$ & $\bullet$ \\
\hline $\begin{array}{l}\text { In cases of treatment failure with other therapeutic } \\
\text { strategies (diet, exercise, psychotherapy, } \\
\text { pharmacotherapy) }\end{array}$ & $\bullet$ & - & $\bullet$ & - & - & - & $\bullet$ \\
\hline Discuss potential risks and benefits with patient & $\bullet$ & - & - & - & - & $\bullet$ & - \\
\hline
\end{tabular}

BMI: body mass index; ICSI: Institute for Clinical Systems Improvement. 
Table 2

Clinical guidelines for treatment of obesity included in the study and assessed with the Appraisal of Guidelines for Research \& Evaluation II (AGREE II) instrument.

\begin{tabular}{|c|c|c|c|}
\hline Country & Institution & $\begin{array}{c}\text { Year of } \\
\text { publication }\end{array}$ & Clinical guideline \\
\hline Argentina 40 & Ministerio de Salud & 2014 & $\begin{array}{l}\text { Guía de Práctica Clínica Nacional sobre Diagnóstico y Tratamiento } \\
\qquad \text { de la Obesidad en Adultos }\end{array}$ \\
\hline Australia 44 & $\begin{array}{l}\text { National Health and Medical Research } \\
\text { Council }\end{array}$ & 2013 & $\begin{array}{l}\text { Clinical Practice Guidelines for the Management of Overweight and } \\
\text { Obesity in Adults, Adolescents and Children in Australia }\end{array}$ \\
\hline Brazil 41 & $\begin{array}{l}\text { Associação Brasileira para o Estudo da } \\
\text { Obesidade e da Síndrome Metabólica } \\
\text { [Brazilian Association for Study of Obesity } \\
\text { and Metabolic Syndrome] }\end{array}$ & 2016 & $\begin{array}{l}\text { Diretrizes Brasileiras de Obesidade [Brazilian Guidelines for } \\
\text { Obesity] }\end{array}$ \\
\hline Belgium 25 & $\begin{array}{l}\text { Domus Medica; Flemish College of General } \\
\qquad \text { Practitioners }\end{array}$ & 2006 & $\begin{array}{l}\text { Aanbeveling voor goede medische praktijkvoering. Overgewicht en } \\
\text { obesitas bij volwassenen in de huisartsenpraktijk }\end{array}$ \\
\hline Canada 34 & $\begin{array}{l}\text { CMAJ (Canadian Medical Association } \\
\text { Journal) }\end{array}$ & 2007 & $\begin{array}{l}2006 \text { Canadian clinical practice guidelines on the management and } \\
\text { prevention of obesity in adults and children }\end{array}$ \\
\hline England 28 & National Guideline Centre & 2014 & $\begin{array}{c}\text { Obesity: Identification, Assessment and Management of Overweight } \\
\text { and Obesity in Children, Young People and Adults: Partial Update } \\
\text { of CG43 }\end{array}$ \\
\hline Finland 26 & $\begin{array}{c}\text { Suomalaisen Lääkäriseuran Duodecimin } \\
\text { ja Suomen Lihavuustutkijat ry:n asettama } \\
\text { työryhmä }\end{array}$ & 2013 & Lihavuus (aikuiset) \\
\hline France 27 & Haute Autorité de Santé & 2011 & $\begin{array}{l}\text { Surpoids et obésité de l'adulte: prise en charge médicale de premier } \\
\text { recours }\end{array}$ \\
\hline Germany 29 & Deutsche Adipositas-Gesellschaft & 2014 & $\begin{array}{c}\text { Interdisziplinäre Leitlinie der Qualität S3 zur, Prävention und } \\
\text { Therapie der Adipositas" }\end{array}$ \\
\hline Italy 30 & Società Italiana dell'Obesità & $2012 / 2013$ & $\begin{array}{l}\text { Standard Italiani per la Cura dell'Obesità - Società Italiana } \\
\text { dell'Obesità, Associazione Italiana di Dietetica }\end{array}$ \\
\hline Malaysia 43 & $\begin{array}{l}\text { Ministry of Health Malaysia, Academy } \\
\text { of Medicine of Malaysia, Malaysian } \\
\text { Association for the Study of Obesity, } \\
\text { Malaysian Endocrine \& Metabolic Society }\end{array}$ & 2004 & Clinical Practice Guidelines on Management of Obesity \\
\hline Mexico 42 & $\begin{array}{l}\text { Centro Nacional de Excelencia Tecnológica } \\
\text { en Salud }\end{array}$ & 2012 & $\begin{array}{c}\text { Prevención, Diagnóstico y Tratamiento del Sobrepeso y la Obesidad } \\
\text { Exógena }\end{array}$ \\
\hline Netherlands 31 & Nederlands Huisartsen Genootschap & 2010 & Obesity (M95). [Obesity (NL: Obesitas)] \\
\hline Norway 32 & $\begin{array}{l}\text { Nasjonale faglige retningslinjer - } \\
\text { Helsedirektoratet }\end{array}$ & 2011 & $\begin{array}{l}\text { Forebygging, utredning og behandling av overvekt og fedme hos } \\
\text { barn og unge }\end{array}$ \\
\hline Scotland 33 & Scottish Intercollegiate Guidelines Network & 2010 & Management of Obesity - A National Clinical Guideline \\
\hline USA 38 & American College of Cardiology & 2013 & $\begin{array}{c}2013 \text { AHA/ACC/TOS Guideline for the Management of Overweight } \\
\text { and Obesity in Adults }\end{array}$ \\
\hline USA 49 & $\begin{array}{c}\text { American Association of Clinical } \\
\text { Endocrinologists and American College of } \\
\text { Endocrinology }\end{array}$ & 2016 & $\begin{array}{c}\text { American Association of Clinical Endocrinologists and American } \\
\text { College of Endocrinology Comprehensive Clinical Practice Guidelines } \\
\text { for Medical Care of Patients with Obesity }\end{array}$ \\
\hline USA 36 & $\begin{array}{l}\text { Department of Veterans Affairs and } \\
\text { Department of Defense }\end{array}$ & 2014 & $\begin{array}{l}\text { VA/DoD Clinical Practice Guideline for Screening and Management } \\
\text { of Overweight and Obesity }\end{array}$ \\
\hline USA 35 & $\begin{array}{l}\text { National Heart, Lung, and Blood Institute } \\
\text { and National Institute of Diabetes and } \\
\text { Digestive and Kidney Diseases }\end{array}$ & 1998 & $\begin{array}{l}\text { Clinical Guidelines on the Identification, Evaluation, and Treatment } \\
\text { of Overweight and Obesity in Adults }\end{array}$ \\
\hline USA 37 & Institute for Clinical Systems Improvement & 2013 & Prevention and Management of Obesity for Adults \\
\hline $\begin{array}{l}\text { World } \\
\text { Gastroenterology }\end{array}$ & World Gastroenterology Organisation & 2011 & World Gastroenterology Organisation Guideline: Obesity \\
\hline Organisation 45 & & & \\
\hline
\end{tabular}


Table 3

Overall assessment of countries' obesity guidelines. Scores are given as percentage (\%) of the maximum total score per individual Appraisal of Guidelines for Research \& Evaluation II (AGREE II) domain.

\begin{tabular}{|c|c|c|c|c|c|c|c|c|}
\hline \multirow[t]{2}{*}{ Study [country (year)] } & \multirow{2}{*}{$\begin{array}{c}\text { Domain } 1 \\
\text { Scope and } \\
\text { purpose } \\
(\%)\end{array}$} & \multirow{2}{*}{$\begin{array}{c}\text { Domain } 2 \\
\text { Stakeholder } \\
\text { involvement } \\
(\%)\end{array}$} & \multirow{2}{*}{$\begin{array}{c}\text { Domain } 3 \\
\text { Rigor of } \\
\text { development } \\
(\%)\end{array}$} & \multirow{2}{*}{$\begin{array}{c}\text { Domain } 4 \\
\text { Clarity of } \\
\text { presentation } \\
\text { (\%) }\end{array}$} & \multirow{2}{*}{$\begin{array}{c}\text { Domain } 5 \\
\text { Applicability } \\
\text { (\%) }\end{array}$} & \multirow{2}{*}{$\begin{array}{c}\text { Domain } 6 \\
\text { Editorial } \\
\text { independence } \\
\text { (\%) }\end{array}$} & \multicolumn{2}{|c|}{ Overall assessment } \\
\hline & & & & & & & $\begin{array}{c}\text { Rate the } \\
\text { overall } \\
\text { quality } \\
\text { of this } \\
\text { guideline. } \\
\text { (1-7) }\end{array}$ & $\begin{array}{l}\text { I would } \\
\text { recommend } \\
\text { this guideline }\end{array}$ \\
\hline Australia (2013) 44 & 100 & 100 & 100 & 100 & 100 & 100 & 7 & Yes \\
\hline England (2014) 28 & 100 & 100 & 97 & 100 & 96 & 92 & 7 & Yes \\
\hline Argentina (2014) 40 & 100 & 89 & 100 & 100 & 85 & 100 & 7 & Yes \\
\hline France (2011) 27 & 100 & 100 & 97 & 97 & 65 & 100 & 6.5 & Yes \\
\hline Mexico (2012) 42 & 100 & 69 & 91 & 100 & 67 & 100 & 6.5 & Yes \\
\hline USA (2013) 37 & 100 & 94 & 78 & 72 & 75 & 100 & 6 & Yes \\
\hline Germany (2014) 29 & 83 & 72 & 100 & 100 & 79 & 96 & 6 & Yes \\
\hline Belgium (2006) 25 & 86 & 61 & 65 & 89 & 52 & 100 & 5.5 & $\begin{array}{c}\text { Yes, with } \\
\text { modifications }\end{array}$ \\
\hline Scotland (2010) 33 & 100 & 97 & 94 & 100 & 63 & 63 & 5.5 & $\begin{array}{c}\text { Yes, with } \\
\text { modifications }\end{array}$ \\
\hline USA (2014) 36 & 100 & 72 & 72 & 83 & 35 & 13 & 5.5 & $\begin{array}{c}\text { Yes, with } \\
\text { modifications }\end{array}$ \\
\hline Canada (2007) ${ }^{34}$ & 94 & 61 & 83 & 100 & 54 & 50 & 5 & $\begin{array}{c}\text { Yes, with } \\
\text { modifications }\end{array}$ \\
\hline Netherlands (2010) 31 & 86 & 97 & 56 & 83 & 63 & 96 & 5 & $\begin{array}{c}\text { Yes, with } \\
\text { modifications }\end{array}$ \\
\hline USA (2013) 38 & 75 & 56 & 96 & 97 & 31 & 96 & 5 & $\begin{array}{c}\text { Yes, with } \\
\text { modifications }\end{array}$ \\
\hline USA (2016) 49 & 100 & 36 & 74 & 100 & 17 & 46 & 5 & $\begin{array}{c}\text { Yes, with } \\
\text { modifications }\end{array}$ \\
\hline USA (1998) 35 & 100 & 100 & 79 & 92 & 48 & 42 & 4 & $\begin{array}{c}\text { Yes, with } \\
\text { modifications }\end{array}$ \\
\hline Italy (2012) 30 & 67 & 42 & 40 & 69 & 10 & 29 & 3.5 & No \\
\hline Brazil (2016) 41 & 78 & 11 & 21 & 64 & 10 & 0 & 3 & No \\
\hline Malaysia (2004) 43 & 69 & 50 & 39 & 47 & 0 & 17 & 3 & No \\
\hline Norway (2011) 32 & 100 & 97 & 49 & 53 & 33 & 38 & 3 & No \\
\hline Finland (2013) 26 & 89 & 47 & 45 & 69 & 4 & 88 & 2 & No \\
\hline $\begin{array}{l}\text { World Gastroenterology } \\
\text { Organisation (2011) } 45\end{array}$ & 39 & 0 & 17 & 48 & 33 & 0 & 2 & No \\
\hline Overall median & 100 & 72 & 78 & 92 & 52 & 88 & & \\
\hline
\end{tabular}

\section{Scope and purpose}

This domain had the greatest convergence in scores among all guidelines assessed, with median of $100 \%$ and interquartile range (IQR) from $81.8 \%$ to 100\%. From the 21 guidelines, 11 received the top score, namely the Argentine, Australian, Scottish, American (NHLBI, Defense Department, ICSI, and AACE), French, English, Mexican and Norwegian guidelines 27,28,32,33,35,36,37,39,40,42,44.

Many guidelines, in addition to the recommendations for adults, included specific recommendations according to population groups such as children and adolescents 25,28,30,31,33,34,39,41,42,43,44, Aborigines or Indigenous peoples 41,44, Asian-descendant populations 34,41,44, older people, and 
pregnant women 30 . Some also had recommendations for subgroups with specific comorbidities 34,41 , according to levels of care (exclusively primary care versus all levels of care $28,33,44$ ), or related to public health $25,28,31,42$.

\section{Stakeholder involvement}

Its median score was $72 \%$ and the IQR was from $49.3 \%$ to $97 \%$. Seven guidelines included no representatives of the users' group 26,29,30,38,39,41,43 in the elaboration of guidelines or review team. In addition, drafting teams for other guidelines consisted mainly of physicians $38,39,41$.

\section{Rigor of development}

The overall score for this domain was relatively high: the median was $78 \%$ and the IQR was from $48 \%$ to $96.3 \%$. The selection and classification of scientific evidence that provided the basis for each recommendation of guidelines varied considerably. The process of evidence selection and appraisal was often unclear. Some guidelines specifically mentioned the use of questions in the PICO format (population, intervention, comparator, outcome) 36,40,44 to orient the search for evidence. Others used reviews of clinical guidelines, produced by other countries or organizations, as the preliminary stage in drafting their own guidelines $29,40,44$ or as part of the evidence compiled in the guideline 42 .

Differences were observed between classification systems for the quality of evidence and the strategies for generating and scoring the strength of recommendation. The Australian guideline, for example, showed the criteria separately for level of evidence (quality of studies), effect size of treatment (relevance of the clinical benefits in the range of the estimate set by the confidence intervals), and estimation of certainty. Based on this, the elements were summarized as a matrix for the body of evidence to support the strength of recommendation 44 .

Meanwhile, some guidelines did not describe the connection between the recommendations and their supporting evidence, showing a summary of recommendations without citing degrees of evidence or the strength of recommendation, or being clear on the process used by guideline developers to make decisions 28,32. The English guideline provided attachments with details on the method for search and selection of evidence, and had high scores in the assessment using AGREE II. Meanwhile, it showed the interventions for obesity as "recommended" and "not recommended", without specifying the degrees of recommendation or levels of evidence 28.

Domain 3 also involved simple issues such as a clear description of search terms and strategies and procedures for updating the guideline, which, curiously, were not made explicit in most guidelines analyzed here. Such procedures and updating timeframes were only described by the German, Argentine, Australian, American (U.S. Department of Defense), French and Scottish guidelines 27,29,33,36,40,44.

\section{Clarity of presentation}

Apart from Brazil, Italy, USA (ICSI), Malaysia, Finland, Norway and the World Gastroenterology Organisation, the other guidelines scored over $80 \%$ in this domain $26,30,32,37,41,43,45$. The overall median was $92 \%$ and the IQR was from $69 \%$ to $100 \%$.

Key recommendations tended to be easily identified in most guidelines. Some guidelines showed their recommendations in a summary of easy access for health professionals 28,33,35,38,40,44.

However, clinical guidelines showed no clear pattern in their content and format. In terms of content, the highest-quality guidelines for obesity took greater care with the contextualization, characterization, epidemiology, diagnostic approaches, and classification of obesity. Nearly all the guidelines had the recommended interventions divided into nutritional/dietetic, behavioral or cognitive, physical activity-related, pharmacological, and surgical.

The formats for presentation also differ. Some guidelines were more explicit in their inclusion of issues that had oriented the recent focus on the dissemination of health information, providing recommendations in various formats to adjust to the reality of distinct audiences. Algorithms with recommendations for obesity management were a key characteristic of the guidelines of studies from USA, Italy, England, Mexico and Norway 28,30,32,35,36,37,38,39,42, but there were also guidelines 
that provided charts with "practical tips" $33,40,42$ or detailed attachments with information on the search for evidence $28,29,38,40,42,44$, for audiences with more available time and the need for more complete information.

\section{Applicability}

This was the domain with the widest range of scores (0\% to 100\%), the lowest median (52\%) and IQR (27.5\% to 69\%). The Australian guidelines scored the highest 44, while Malaysian, Finnish, Brazilian and Italian guidelines scored the lowest $26,30,41,43$. The overall score of this domain reveals an insufficient perception of the importance of including recommendations for the implementation of guidelines. Only the Australian guidelines reached 100\% of the score as assessed by AGREE II, followed by the English one, with 96\% 28,44.

Most guidelines failed to suggest implementation tools for recommendations. One exception was the guideline from the ICSI 37 , in which implementation strategies were an explicit objective. This guideline had special attention to the implementation issue, including the recommendation of indicators and measures for monitoring obesity in the population.

The Argentine guideline was one of the few that proposed a strategic planning tool to increase the opportunities for its use, such as the Guideline Implementation Appraisal (GLIA) 40.

Another important issue that received little attention in this domain considers the resources required to apply the recommendations. Lack of resources can pose an obvious barrier to the applicability of recommendations. Only the guidelines from Australia 44, England 28, and Germany 29 explicitly addressed this issue. A single guideline, from the World Gastroenterology Organisation 45, linked the recommended interventions to the availability of resources according to the country's income level (high, medium, and low income), although this link was schematic. The main impact of this resource gradient was seen in the recommendation for pharmacological and bariatric treatment. For high-income countries, the guidelines recommended bariatric surgery for patients with BMI from 30 to $35 \mathrm{~kg} / \mathrm{m}^{2}$, compared to the recommendation in low-income countries, where the cutoff is $\mathrm{BMI}>40 \mathrm{~kg} / \mathrm{m}^{2}$.

\section{Editorial independence}

Domain 6 also showed wide variation between the guidelines analyzed, IQR from $35.8 \%$ to $100 \%$ and median of $88 \%$. The guidelines that scored highest in this domain were the Argentine, Australian, American (ICSI), Belgian, Mexican and French 25,27,37,40,40,44. We highlight that the guidelines that failed to report the existence or absence of conflicts of interest and possible influences from funding agencies or industries also had the lowest score in this domain 30,32,36,41,43.

The mere description of presence or absence of conflict of interest does not automatically increase the score of the guideline when its drafting committee includes members affiliated with industry or who have an economic interest in the sale of products or medicines for obesity. This item assesses whether the drafting committee made any attempt to minimize the influence of conflicts of interest in the drafting process of the guideline or in the formulation of recommendations.

\section{Therapeutic recommendations in the best scoring guidelines}

A synthesis of the main treatment approaches recommended in the best ranked guidelines $27,28,29,37,40,42,44$ is shown in Table 1 . Dietary recommendations emphasize reducing intake of food and fat by 500-1,000 calories/day. In addition, physical activity, varying from a minimum of 150 minutes a week to 300 minutes/week, is widely recommended.

The best scoring guidelines uniformly recommended psychological follow-up based on cognitivebehavioral therapy. Recommendations concerning pharmacotherapy in most guidelines restricted its use to patients with BMI exceeding $30 \mathrm{~kg} / \mathrm{m}^{2}$ and to the drug Orlistat, a gastric and pancreatic lipase inhibitor. Bariatric surgery is recommended for BMI $>40 \mathrm{~kg} / \mathrm{m}^{2}$ for patients in whom other treatment approaches failed. France provided no recommendations related to these last two types of interventions. 


\section{Discussion}

Most countries included in this study are in the Organization for Economic Co-operation and Development (OECD) where average prevalence of self-reported obesity was $18.4 \%$ (2013), with a $27 \%$ increase from 2000 to 2013. Italy (10\%), Norway (10.3\%), Netherlands (11.1\%), Belgium (13.7\%) and France (14.5\%) showed rates below the OECD average. The French growth rate of obesity of $61 \%$ in 13 years is an alarming matter of concern. USA (35.3\%) and Mexico (32.4\%) showed the highest levels of self-reported obesity, whereas Germany, Finland, England and Canada had obesity rates ranging from $23.6 \%$ to $25.8 \% 46$. Australia outstood due to its high rate of self-report obesity at $28.3 \%$ in 2013 and rapid growth of this condition (43\% from 1995 to 2011), as is the case of many countries of the Asia-Pacific region. For Malaysia, however, obesity rates registered in 2014 were 10.6\% (males) and $16 \%$ (females) 47 .

Curiously, countries with lower prevalence of obesity (Italy, Norway and Malaysia) had the worst ranks and older guidelines, pointing to a possible lower prioritization of the condition compared to other countries selected in this study. Additionally, for USA, with the highest prevalence of obesity, five guidelines were found.

As observed in previously published analyses of guidelines 17,18,48, between one fourth and one third failed to achieve the minimum quality standards. In our study, the guideline with the best assessment was the Australian, which received the highest score in all the domains. Except for the guideline from Canada (country where the AGREE instrument was developed), the three guidelines drafted before the AGREE tended to show worse quality than those drafted since the instrument was published 19, suggesting that it had been used in the development of guidelines. The explicit mention to the use of the AGREE instrument for guideline development was only reported by Argentina, USA (ICSI) and England (National Institute for Health and Clinical Excellence - NICE) 28,40,49.

Some authors highlighted that guidelines developed by professional associations generally have lower scores than those produced by government agencies 17,48,50. Of the seven guidelines with the highest scores, five (Australia, England, Argentina, France, and Mexico) were produced by the government agency responsible for health in that country. The German guideline, which had a high score, had a rare characteristic for guidelines, namely the fact that it was drafted jointly by 11 associations and specialty societies, ranging from family physicians to nutritionists, bariatric surgeons, and diabetes and obesity societies. The quality of guidelines may thus reflect the diversity of professional categories involved in the guideline drafting process, emphasizing the fact that obesity is a multifactorial disease that requires a multidisciplinary and multicomponent approach.

Although many of the obesity guidelines were drafted by government agencies, the focus was primarily for interventions in individual health, with limited attention to recommendations linked to public policies in most of the documents. England outstood with an integrated guideline for both clinical practice and public health. It specified that obesity cannot be addressed only at the individual level and highlighted the importance of the environment and public policies. It featured a long list of advices that precede the clinical recommendations, related to the need for involvement by government authorities and "budget holders", training of professionals for the recommended levels of care, and public awareness-raising (including teachers) on healthy lifestyles 28 .

The elaboration of guidelines and the evidence-based medicine movement 51 obviously converge in the incorporation of questions in the PICO format (population, intervention, control, and outcome). This format is used as the basis for gathering evidence in some guidelines and takes into consideration the patients' involvement in the guideline drafting process. The overall score in the "stakeholder involvement" domain suggests difficulty in integrating patients in the discussion of treatment approaches, unlike evidence-based medicine, in which the patient's preferences have played an increasingly central role 51 .

In the overall assessment of guidelines, the domains (1) "scope and purpose" (median of 100\%) and (4) "clarity of presentation" (median of 92\%) had the highest score. The domains with the lowest scores were (5) "applicability" (median of 52\%) and "stakeholder involvement" (median of 72\%).

Moreover, the German guideline conducted a review of ten guidelines for obesity 29 , based on the German Instrument for the Methodological Appraisal of Guidelines (DELBI), which is a quality assessment instrument, quite similar to the AGREE II (DELBI incorporates six domains from AGREE II and 
includes two additional domains). The study had already shown the potential for improvement in the domains "stakeholder involvement" (DELBI domain 2) and "general applicability" (DELBI domain 5), as well as in the domain "methodological rigor of development" (DELBI domain 3). Although 15 of the guidelines assessed in our study were drafted after those assessed in the German review, there are still some inadequacies in these domains.

Problems related to the lack of adequacy in the domain "methodological rigor of development" confirm findings from studies prior to the creation of AGREE 17,18,52. A study by Grilli et al. 17 analyzed 431 guidelines developed by professional societies from 1988 to 1998 and found that only $12 \%$ provided information on the levels of evidence and grading of recommendations. Some recent studies 53, a few conducted in countries such as Korea 13 and Brazil 21, also identified shortcomings in the guideline development process as one of the aspects that most contributed to the low quality of guidelines.

"Applicability" was the domain that had the lowest score among those assessed by AGREE II. By failing to describe tools for their application and possible barriers, many guidelines gave little attention to mechanisms for facilitating their implementation in clinical practice. According to Locatelli et al. 54, the implementation of clinical guidelines is the only way to ensure that health outcomes will be improved. In Brazil, a study to assess the use of clinical guidelines for arterial hypertension in primary care showed low adherence to guidelines by professionals in the Family Health Program and reiterated the importance of guaranteeing the necessary resources and strategies to implement changes in routine health services 55 .

In addition to quality differences, the guidelines analyzed in this study differed in their treatment recommendations. Treatment recommendations are not assessed by the AGREE II instrument, but the best-ranked guidelines showed relative consistency in this aspect. Considering low-quality guidelines, the recommendations may differ significantly in content and in the direction of strength of evidence, when compared to higher-quality guidelines.

Although recommendations for obesity treatment seemed simple and consensual in the best scoring guidelines, most of them required changes in individual behavioral patterns and lifestyle contexts, which may be very difficult to achieve. Implementation barriers were evident, inasmuch as "applicability" remained the domain with lowest scores. Additionally, despite adverse events related to them, surgical and pharmaceutical interventions emerged as rapid solutions from the patient's perspective, potentially leading to overuse of these approaches.

The potential limitations of the AGREE II instrument and the subjectivity of the score of domains are worth mentioning, even though we identified this issue and conducted the assessment carefully. Also, we did not assess the cutoff points that allowed recommending the guideline ("I recommend this guideline"), which could lead to different choices in terms of recommending or not recommending the guidelines.

Developers of the Argentine obesity guidelines 40 had previously assessed, as part of their guideline development process, 25 obesity guidelines based on the AGREE II. They opted not to establish cutoffs for recommending a guideline, but instead they ranked a group of guidelines as "highly recommended". "Highly recommended" guidelines were those which received a minimum of $60 \%$ of highest scores in four domains, necessarily including "rigor in development", and at least 30\% in the remaining ones. They thus selected six guidelines, all of which were also included in our study 28,33,34,36,39,40. The sequence established on ranking guidelines of countries by quality scores was very similar to our results. The consistency between these two independent scoring processes points to the reliability of the AGREE II as a quality assessment instrument.

\section{Final considerations}

According to Locatelli et al. 54, although guidelines are an important instrument for promoting the quality of patient care, they can also be disadvantageous if they neither defend the best treatment options for patients, nor specify the areas in which there are still scientific uncertainties.

Obesity is a global health problem, and various countries have produced clinical guidelines for interventions to address this problem. The quality of the guidelines, as assessed by AGREE II, is 
extremely heterogeneous. The Reporting Items for Practice Guidelines in Healthcare (RIGHT) checklist is the most recent addition to instruments dealing with quality problems in practice guidelines 56 . This checklist from 2017 addresses a number of problems pointed out in our study concerning obesity guidelines. Among others, we highlight the requirement for greater emphasis on: a detailed description of the selection process of guideline developers; the statement of the key question in a PICO format; and a clearer description of the rationale for recommendations, especially of approaches used by guideline developers to appraise evidence, make decisions and formulate the recommendations.

Guideline development and quality enhancement are ongoing processes requiring systematic appraisal of the guidelines under production process and existing guidelines. We recommend a wider use of the instruments for guideline development.

\section{Contributors}

E. C. Reis, S. R. L. Passos and M. A. B. Santos participated in the study design, assessment of the guidelines, and elaboration of the manuscript.

\section{Acknowledgments}

E. C. Reis received a PhD scholarship from the Brazilian Graduate Studies Coordinating Board (Capes). S. R. L. Passos had a research productivity scholarship from Brazilian National Research Council (CNPq, n. 310765/2016-1).

\section{References}

1. NCD Risk Factor Collaboration. Trends in adult body-mass index in 200 countries from 1975 to 2014: a pooled analysis of 1698 population-based measurement studies with 19.2 million participants. Lancet 2016; 387:137796.

2. World Health Organization. Obesity and overweight. http://www.who.int/mediacentre/ factsheets/fs311/en/ (accessed on 04/Feb/ 2015).

3. Instituto Brasileiro de Geografia e Estatística. Pesquisa Nacional de Saúde 2013. Ciclos de vida: Brasil e grandes regiões. Rio de Janeiro: Instituto Brasileiro de Geografia e Estatística; 2015.

4. Ministério da Saúde. Portaria no 424, de 19 de março de 2013. Redefine as diretrizes para a organização da prevenção e do tratamento do sobrepeso e obesidade como linha de cuidado prioritária da Rede de Atenção à Saúde das Pessoas com Doenças Crônicas. Diário Oficial da União 2013; 20 mar.

5. Rotter T, Kinsman L, Machotta A, Zhao F, van der Weijden T, Ronellenfitsch U, et al. Clinical pathways for primary care: effects on professional practice, patient outcomes, and costs. Cochrane Database Syst Rev 2013; (8):CD10706.

6. Revere D, Turner AM, Madhavan A, Rambo N, Bugni PF, Kimball A, et al. Understanding the information needs of public health practitioners: a literature review to inform design of an interactive digital knowledge management system. J Biomed Inform 2007; 40:410-21.

7. Institute of Medicine. Clinical practice guidelines: directions for a new program. Washington DC: National Academies Press; 1990.

8. Grimshaw JM, Russell IT. Effect of clinical guidelines on medical practice: a systematic review of rigorous evaluations. Lancet 1993; 342:1317-22. 
9. Smith T, Hillner B. Ensuring quality cancer care by the use of clinical practice guidelines and critical pathways. J Clin Oncol 2001; 19:2886-97.

10. Woolf S, Grol R, Hutchinson A, Eccles M, Grimshaw J. Clinical guidelines: potential benefits, limitations, and harms of clinical guidelines. BMJ 1999; 318:527-30.

11. Grol R. Successes and failures in the implementation of evidence-based guidelines for clinical practice. Med Care 2001; 39:46-54.

12. Taba P, Rosenthal M, Habicht J, Tarien H, Mathiesen M, Hill S, et al. Barriers and facilitators to the implementation of clinical practice guidelines: a cross-sectional survey among physicians in Estonia. BMC Health Serv Res 2012; 12:455.

13. Choi T-Y, Choi J, Lee JA, Jun JH, Park B, Lee MS. The quality of clinical practice guidelines in traditional medicine in Korea: appraisal using the AGREE II instrument. Implement Sci 2015; 10:104.

14. Brouwers MC, Kho ME, Browman GP, Burgers JS, Cluzeau F, Feder G, et al. AGREE II: advancing guideline development, reporting and evaluation in health care. CMAJ 2010; 182:E839-42.

15. Cates JR, Young DN, Guerriero DJ, Jahn WT, Armine JP, Korbett AB, et al. Evaluating the quality of clinical practice guidelines. J Manipulative Physiol Ther 2001; 24:170-6.

16. AGREE Collaboration. Development and validation of an international appraisal instrument for assessing the quality of clinical practice guidelines: the AGREE project. Qual Saf Health Care 2003; 12:18-23.

17. Grilli R, Magrini N, Penna A, Mura G, Liberati A. Practice guidelines developed by specialty societies: the need for a critical appraisal. Lancet 2000; 355:103-6.

18. Shaneyfelt T, Mayo-Smith M, Rothwangl J. Are guidelines following guidelines? The methodological quality of clinical practice guidelines in the peer-reviewed medical literature. JAMA 1999; 281:1900-5.

19. Consórcio AGREE. Instrumento para avaliação de diretrizes clínicas AGREE II. https:// www.agreetrust.org/wp-content/uploads/ 2013/06/AGREE_II_Brazilian_Portuguese. pdf (accessed on 17/Jan/2017).

20. Ronsoni RDM, Pereira CCA, Stein AT, Osanai MH, Machado CJ. Avaliação de oito Protocolos Clínicos e Diretrizes Terapêuticas (PCDT) do Ministério da Saúde por meio do instrumento AGREE II: um estudo piloto. Cad Saúde Pública 2015; 31:1157-62.

21. Molino CGRC, Romano-Lieber NS, Ribeiro E, Melo DO. Non-communicable disease clinical practice guidelines in Brazil: a systematic assessment of methodological quality and transparency. PLoS One 2016; 11:e0166367.

22. Cotrim HP, Parise ER, Figueiredo-Mendes C, Galizzi-Filho J, Porta G, Oliveira CP. Nonalcoholic fatty liver disease Brazilian Society of Hepatology consensus. Arq Gastroenterol 2016; 53:118-22.
23. Westphal GA, Garcia VD, Souza RL, Franke CA, Vieira KD, Birckholz VRZ, et al. Diretrizes para avaliação e validação do potencial doador de órgãos em morte encefálica. Rev Bras Ter Intensiva 2016; 28:220-55.

24. Khan GS, Stein AT. Adaptação transcultural do instrumento Appraisal of Guidelines for Research ef Evaluation II (AGREE II) para avaliação de diretrizes clínicas. Cad Saúde Pública 2014; 30:1111-4.

25. van Royen $P$, Bastiaens H, D'Hondt A, Provoost C, Van Der Borght W. Overgewicht en obesitas bij volwassenen en in de huisartsenpraktijk: aanbeveling voor goede medische praktijkvoering. Belgian. Huisarts Nu april 2006; 35(3).

26. Suomalaisen Lääkäriseuran Duodecimin ja Suomen Lihavuustutkijat ry:n asettama työryhmä. Helsinki: Käypä hoito; 2013.

27. Haute Autorité de Santé. Surpoids et obésité de l'adulte: prise en charge médicale de premier recours. Recommandation de bonne pratique. Saint-Denis-la-Plaine: Service des bonnes pratiques professionnelles, Haute Autorité de Santé; 2011.

28. National Institute for Health and Care Excellence. Obesity: identifification, assessment and management: clinical guideline CG189. London: National Institute for Health and Care Excellence; 2014.

29. Berg A, Bischoff SC, Colombo-Benkmann M. Ellrott T, Hauner H, Heintze C, et al. Interdisziplinäre Leitlinie der Qualität S3 zur "Prävention und Therapie der Adipositas". Planegg: Deutsche Adipositas-Gesellschaft; 2014.

30. Società Italiana dell'Obesità; Associazione Italiana di Dietetica. Standard Italiani per la cura dell'obesità. Pisa: Società Italiana dell'Obesità; 2012.

31. Van Binsbergen JJ, Langens FNM, Dapper ALM, Van Halteren MM, Glijsteen R, Cleyndert GA, et al. Nederlands Huisartsen Genootschap (NHG): standaard obesitas. Huisarts Wet 2010; 53:609-25.

32. Helsedirektoratet. Forebygging, utredning og behandling av overvekt og fedme hos voksne Nasjonale retningslinjer for primærhelsetjenesten. Oslo: Norwegian Directorate of Health; 2011.

33. Scottish Intercollegiate Guidelines Network. Management of obesity: a national clinical guideline. Edinburgh: NHS Improvement; 2010.

34. Lau DC, Douketis JD, Morrison KM, Hramiak IM, Sharma AM, Ur E, et al. 2006 Canadian clinical practice guidelines on the management and prevention of obesity in adults and children [summary]. CMAJ 2007; 176(8 Suppl):S1-13.

35. National Heart, Lung, and Blood Institute. Clinical guidelines on the identification, evaluation, and treatment of overweight and obesity in adults - the evidence report. Bethesda: National Heart, Lung, and Blood Institute; 1998. (National Institutes of Health Publication, 984083). 
36. The Management of Overweight and Obesity Working Group. VA/DoD clinical practice guideline for screening and management of overweight and obesity. Washington DC: Department of Veterans Affairs, Department of Defense; 2014.

37. Fitch A, Everling L, Fox C, Goldberg J, Heim C, Johnson $\mathrm{K}$, et al. Prevention and management of obesity for adults. Bloomington: Institute for Clinical Systems Improvement; 2013.

38. Jensen MD, Ryan DH, Apovian CM, Ard JD, Comuzzie AG, Donato KA, et al. 2013 AHA/ ACC/TOS guideline for the management of overweight and obesity in adults: a report of the American College of Cardiology/American Heart Association Task Forcemon Practice Guidelines and The Obesity Society. J Am Coll Cardiol 2014; 63(25 Pt B):2985-3023.

39. Garvey WT, Mechanick JI, Brett EM, Garber AJ, Hurley DL, Jastreboff AM, et al. American Association of Clinical Endocrinologists and American College of Endocrinology comprehensive clinical practice guidelines for medical care of patients with obesity. Endocr Pract 2016; 22 Suppl 3:1-203.

40. Ministerio de Salud de la Nación. Guía de práctica clínica nacional sobre diagnóstico y tratamiento de la obesidad en adultos. Buenos Aires: Ministerio de Salud de la Nación; 2014.

41. Associação Brasileira para o Estudo da Obesidade e da Síndrome Metabólica. Diretrizes brasileiras de obesidade 2016. 4ạ Ed. São Paulo: Associação Brasileira para o Estudo da Obesidade e da Síndrome Metabólica; 2016.

42. Pérez EC, Morales EEM, Salazar LM. Prevención, diagnóstico y tratamiento del sobrepeso y la obesidad exógena. México DF: Centro Nacional de Excelencia Tecnológica en Salud, Secretaría de Salud; 2012.

43. Ministry of Health; Academy of Medicine of Malaysia; Malaysian Association for the Study of Obesity; Malasian Endocrine \& Metabolic Society. Clinical practice guidelines on management of obesity. Putrajaya: Ministry of Health; 2014.

44. National Health and Medical Research Council. Clinical practice guidelines for the management of overweight and obesity in adults, adolescents and children in Australia. Melbourne: National Health and Medical Research Council; 2013.

45. Fried M, Khan AG, Garisch J. World Gastroenterology Organisation Global Guideline. WGO practice guidelines: obesidade (versão completa-português). Milwaukee: World Gastroenterology Organisation; 2011.
46. Organisation for Economic Co-operation and Development. Health at a glance 2015. OECD indicators. http://dx.doi.org/10.1787/health_ glance-2015-en (accessed on 20/Jul/2017).

47. Organisation for Economic Co-operation and Development; World Health Organization. Health at a glance: Asia/Pacific 2016. Measuring progress towards universal health coverage. http://dx.doi.org/10.1787/health_glance_ ap-2016-en (accessed on 20/Jul/2017).

48. Burgers JS, Grol R, Klazinga NS, Mäkelä M, Zaat J; AGREE Collaboration. Towards evidence-based clinical practice: an international survey of 18 clinical guideline programs. Int J Qual Health Care 2003; 15:31-45.

49. World Health Organization. Physical status: the use and interpretation of anthropometry. Geneva: World Health Organization; 1995. (WHO Technical Report Series, 854).

50. Hasenfeld R, Shekelle PG. Is the methodological quality of guidelines declining in the US? Comparison of the quality of US Agency for Health Care Policy and Research (AHCPR) guidelines with those published subsequently. Qual Saf Health Care 2003; 12:428-34.

51. Guyatt G, Drummond R, Meade M, Cook D. Users' guides to the medical literature: a manual for evidence-based clinical practice. The Evidence-Based Medicine Working Group. Chicago: JAMA \& Archives Journals AMA Press; 2013.

52. Arnau JM, Vallano A, Lopez A, Pellisé F, Delgado MJ, Prat N. A critical review of guidelines for low back pain treatment. Eur Spine J 2006; 15:543-53.

53. Nothacker M, Stokes T, Shaw B, Lindsay P, Sipilä R, Follmann M, et al. Reporting standards for guideline-based performance measures. Implement Sci 2016; 11:6.

54. Locatelli F, Andrulli S, Del Vecchio L. Difficulties of implementing clinical guidelines in medical practice. Nephrol Dial Transplant 2000; 15:1284-7.

55. Lima SML, Portela MC, Koster I, Escosteguy CC, Ferreira VMB, Brito C, et al. Utilização de diretrizes clínicas e resultados na atenção básica à hipertensão arterial. Cad Saúde Pública 2009; 25:2001-11.

56. Chen Y, Yang K, Marušic A, Qaseem A, Meerpohl JJ, Flottorp S, et al. A reporting tool for practice guidelines in health care: the RIGHT Statement. Ann Intern Med 2017; 166:128-32. 


\section{Resumo}

Existem diversas diretrizes para o tratamento da obesidade, e a qualidade dessas diretrizes clinicas tem suscitado preocupação. O estudo teve como objetivo descrever e avaliar a qualidade das diretrizes clinicas para o tratamento da obesidade em adultos. Identificamos diversos estudos publicados entre 1998 e 2016 e produzidos em diferentes paises. A busca na literatura incluiu a National Guideline Clearinghouse (NGC), Guidelines International Network (GIN), PubMed (MEDLINE), Scopus, Web of Science, websites de instituições sanitárias de diversos países e sites de busca, com o critério: "diretrizes clínicas para o tratamento da obesidade em adultos, publicadas até 2016". As diretrizes foram avaliadas com a Appraisal of Guidelines for Research \& Evaluation (AGREE II), de acordo com os domínios do instrumento. A busca identificou 21 diretrizes: nove da Europa, seis da América do Norte, três da América Latina e uma da Ásia uma da Oceania e uma associação transnacional. A diretriz australiana recebeu a melhor avaliação. Das seis diretrizes que receberam as melhores avaliações, cinco haviam sido elaboradas pela respectiva autoridade sanitária nacional. Os domínios "escopo e objetivo" e "clareza de apresentação" receberam as pontuações mais altas. Com exceção da diretriz canadense, as três diretrizes publicadas antes da elaboração do instrumento AGREE II apresentaram a pior qualidade. No dominio "envolvimento dos stakeholders", apenas quatro (da Austrália, Escócia, França e Inglaterra) mencionaram a participação dos pacientes. O desenvolvimento e melhoria da qualidade das diretrizes são processos permanentes que exigem a avaliação sistemática do processo de produção e das diretrizes existentes.

Obesidade; Guias de Prática Clínica como Assunto; Avaliação de Tecnologias em Saúde

\section{Resumen}

Existen varias líneas de actuación para el tratamiento de la obesidad, y por este motivo la calidad de las guías clinicas se ha convertido en un asunto de interés general. El objetivo de este trabajo fue describir y evaluar la calidad de las guías clinicas para el tratamiento de la obesidad en adultos. Recogimos varios estudios, entre 1998 y 2016, realizados en diferentes países. La búsqueda de bibliografía incluyó: National Guideline Clearinghouse (NGC), Guidelines International Network (GIN), PubMed (MEDLINE), Scopus, Web of Science, páginas web de instituciones de salud de diferentes países, y páginas de búsqueda, con el criterio: "guías clinicas para el tratamiento de la obesidad en adultos y publicadas hasta 2016”. Las guías fueron evaluadas con el Appraisal of Guidelines for Research \& Evaluation (AGREE II), según los diferentes ámbitos de este instrumento. La búsqueda identificó 21 guías: nueve procedentes de Europa, seis de Norteamérica, tres de Latinoamérica, una de Asia, una Oceanía y una con asociación transnacional entre ellos. La guía australiana contaba con la mejor evaluación. De las seis guías con las puntuaciones más altas, cinco habian sido elaboradas por el sector del gobierno responsable de la salud del país. Los campos "alcance y propósito" y "claridad de la presentación" contaban con la puntuación más alta. Excepto en el caso de la guía canadiense, las tres guías redactadas antes de la elaboración del AGREE II tenían peor calidad. En el campo "participación de las partes interesadas", sólo cuatro guías (Australia, Escocia, Francia, e Inglaterra) mencionaron la participación del paciente. Las guías para el desarrollo y mejora de la calidad son procesos en curso que requieren una evaluación sistemática del proceso de producción de las guías y de las directrices existentes.

Obesidad; Guías de Práctica Clínica como Asunto; Evaluación de Tecnologías en Salud
Submitted on 24/Mar/2017

Final version resubmitted on 23/Oct/2017

Approved on 13/Nov/2017 